\title{
Variables of Risk Management in Sports among Sports Administrators: A Mixed Method
}

\author{
Linda N. Chukwurah, Umar Badaru, Oliver R. Ngwoke, Oliver I. Abbah* \\ Department of Human Kinetics and Health Education, University of Nigeria, Nsukka, Nigeria
}

Received December 28, 2020; Revised February 24, 2021; Accepted March 12, 2021

\section{Cite This Paper in the following Citation Styles}

(a): [1] Linda N. Chukwurah, Umar Badaru, Oliver R. Ngwoke, Oliver I. Abbah, "Variables of Risk Management in Sports among Sports Administrators: A Mixed Method," International Journal of Human Movement and Sports Sciences, Vol. 9, No. 2, pp. 324 - 333, 2021. DOI: 10.13189/saj.2021.090221.

(b): Linda N. Chukwurah, Umar Badaru, Oliver R. Ngwoke, Oliver I. Abbah (2021). Variables of Risk Management in Sports among Sports Administrators: A Mixed Method. International Journal of Human Movement and Sports Sciences, 9(2), 324 - 333. DOI: 10.13189/saj.2021.090221.

Copyright $C 2021$ by authors, all rights reserved. Authors agree that this article remains permanently open access under the terms of the Creative Commons Attribution License 4.0 International License

\begin{abstract}
Risks are inevitable in sports activities and organizations; however, there are increasing occurrences of risks in Nigeria sports organizations in spite of standard risk management process. This study therefore examined socio-demographics determining risks management among sports administrators in Nigeria. Mixed method design was adopted. 150 coaches provided quantitative data by completing a validated questionnaire. 10 interview sessions were conducted among 10 sports administrators for the qualitative data. Pre-tested validated questionnaire and an in-depth interview guide were used for collecting data. Descriptive statistics T-test and ANOVA were used to analyze the quantitative data. Using NVivo 11 pro, qualitative data were coded and thematically analyzed, and data were presented using verbatim quotes. It was found that type of sports $(p=>.05)$, educational level $(p=>.05)$ and job experience $(\mathrm{p}=>.05)$ did not exert significant differences on risks management of sports administrators. However, the qualitative data show that majority of the participants view interactions between the variables and application of risks management, which is in line with contingency theory. The findings have implications for the effective risk management in Nigeria sports. Therefore, Nigeria sports governing bodies must demonstrate commitment and establish strong alignments between socio-demographics of sports administrators/managers and practice. These would ensure best practices in sports councils/organizations.
\end{abstract}

Keywords Risks in Sports, Type of Sports, Job Experience, Education Level, Sports Administrators

\section{Introduction}

Globally, there is increasing risks of litigations and injuries in sports, physical education, and recreation organizations. Preston Plevretas sued $\mathrm{La}$ Salle in Philadelphia for improper treatment after sustaining concussion during practice of which the sum of $\$ 7.5$ million was awarded as compensation (20). Also, in a report by (15) Las Awaras County sports administrators in Mexico were found liable and the sum of $\$ 3.1$ million was lost in compensation. Providing safe events and activities are always the goal of sports administrators, however, (12) found higher risk of injuries to be associated to team sports such as soccer and basketball than individual sports like skiing, tennis and athletics. In Nigeria, (18) found football (soccer) as sports with the highest record of injury at $73.8 \%$ as compared to other sports activities.

Sports organizations also experience loss through damage of facilities. According to (19), South-Lakes athletic facilities which were installed with \$1.4million got severally damaged as a result of vandalism. Though there is sparse of data on Nigeria, sports facilities suffer reoccurring damage as result of vandalism. This makes government to spend millions of naira on reconstruction and renovation of sports facilities very often, especially, during major sports competitions/events. All these have significant impact on the performance of athletes, sports activities delivery and subsequent financial state of sports 
organizations.

Sports administrators (managers) are saddled with the responsibilities of ensuring safe delivery of sports activities and the success of sports organizations (councils). Functions of sports administrators include; aiding athletes in the development of technical skills; improving and producing performances from the team; understanding and motivating the players for good results; understanding each player's weakness and strength, safe guarding and protecting the interest of the team and organization (10). The increasing exposure of sports organizations to the effects of numerous risks has made effective risk management very pertinent. (23) similarly noted that the changing scope of liability cases has led to the increased interest in risks management among sports managers and organizations.

Risks management is an important tool in sports management process which is used to predict and even avoid unamiable situations like accidents, injuries, and loss (8). It aims at not eliminating risks in sports, rather effective handling of risks in all sports activities and organizations, maximizing opportunities and decreasing adverse effects (3). Effective risks management in sports helps sports administrators to prevent preventable harm in sports activities which may lead to injuries or litigations, and give the administrators the opportunity to map out ways to handle such situations should they eventually occur. (11) noted that risks management in sports sorts to create a safer environment and legally safer operational procedures for sports administrators and sports organizations. With knowledge of risks management, sports administrators are readily alert, prepared and armed with the necessary tools or strategies to deal with risks in sports activities without delay. In support, (7) stated that a sound and effective risks management in sports minimizes the likelihood of injury and reduces chances of negligence, thus, helping to ensure quality programmes in safe environment.

Specified process of risks management includes: identification of risks (distinguishing possible risks), assessing the risks (analyzing probable impact of identified risks), risks treatment (managing or mitigating the risks depending on its nature which can be through avoidance, retention or risks transfer) and risk monitoring (ensuring effectiveness of the process and identifying new risks) (11). These steps are geared towards reducing the chances of injury, enhancing the protection of sports facilities from damages, and assisting sports administrators to minimize the rate of liability cases. However, this standardized risks management process in sports has not made any practical impact among sports organizations in Nigeria, hence, the urgent need to ascertain socio-demographic variables of sports administrators in state sports councils.

Researches have shown that there are variables pivotal to risks management in sports. (2) in a study found that two primary factors that influenced sports directors' risks management in sports behaviours were years of working and nature of the sports. (22) found contact sports and years of experience to be the key factors affecting higher responses of risks management practices and legal considerations in South Korean sports clubs. On the other hand, (1) found the following results: significant relationship between experience and risks management practices; no significant relationship between academic level and risk management practices; and significant relationship between sports type and risks management practice of Acqua complex manager of Khorasan Razavi. Despite the global increase in awareness of risks management in sports, none of the studies focused on sports administrators in Nigeria. Therefore, this study sets out to ascertain if type of sports, level of education and job experience of sports administrators exert significant differences on risks management in State sports councils, South East, Nigeria.

There are theories of management/administration utilized by sports administrators/managers as guide to the delivery of functions and sports programmes such as behavioural theory by Elton Mayo of 1924 and administrative management theory of 1916 by Henri Fayol. However, situating this study is the contingency theory of 1956 by Joan Woodward. This theory holds the view that there is no universal or one best way to manage an organization; the design of the organization and its subsystem must fit with the environment. According to the theory, human resources and environment should be put into consideration for administrative success to be achieved, and this is applicable to sports organizations. In relation to the present study, being that there is no best way of managing risks in sports councils, the nature of sports activity and other variables such as education level and experience of the sports administrators should be pivotal in ensuring efficient risks management. These are indices that play vital role in determing an administrator's choice and application of risks management strategy at any point. Thus it is of great importance to ascertain these variables among sports administrators with regards to effective management of risks. Hypotheses were derived from results of previous studies such as 1,2, and 22 .

\subsection{Research Hypotheses}

1. There is no significant difference on risks management of sports administrators in state sports councils south-east Nigeria based on type of sport.

2. There is no significant difference in the risks management of the sports administrators in state sports councils south-east Nigeria according to education level.

3. There is no significant difference in the risks management of the sports administrators in state sports councils south-east Nigeria based on job experience. 


\section{Methods}

\subsection{Study Area and Duration}

The study was carried out across state sports councils in South East, Nigeria. Choice of the area was made because the region engages actively in sports competitions such as biennial national sports festival, yearly Akanu ibiam U18 football tournament, among others, and the sports administrators are constantly faced with risks during practices or actual competitions. These possible harms may lead to financial loss to the sports council through litigations.

\subsection{Design}

The study adopted mixed method research design. The design enables a researcher to collect and analyze both quantitative and qualitative data in order to provide further understanding to the research problem.

\subsection{Participants}

The study involved a total of 160 respondents: $96 \%$ males and $4 \%$ females from five state sports councils in the South-Eastern region of Nigeria. 150 sports coaches: team sports $98(65 \%)$ and $52(35 \%)$ individual sports coaches provided the quantitative data. These are coaches employed in the various state sports councils in the south-east to train athletes for the various national and international competitions and maintain sports facilities in the states. As such, these coaches are usually exposed to different risks in sports as they discharge their duties. In addition, 10 sports administrators (Director and deputy directors of sports); $100 \%$ males, provided the qualitative data. The sports administrators are charged with the duty of ensuring that sports councils perform successfully with minimal risks such as financial loss and damage of sports facilities.

\subsection{Instrument}

Structured questionnaire was used for collecting the quantitative data. Items of the questionnaire were prepared through the review of related literature on risks management. First part of the questionnaire contained the socio-demographic data of the respondents while the second part contained items on risks management process in sports. Validity of the instruments (questionnaire and In-depth interview guide) were established by five experts which are sports administrators and professors of Human Kinetics and Sports studies. The reliability of the questionnaire was established by pre-testing the questionnaire on 20 sports coaches and administrators in Delta state sports council (outside the study area but with the same characteristics with the respondents under study).
Cronbach Alpha statistics was used to determine the reliability of the questionnaire of which 860 reliability coefficient indexes were obtained. The researchers and two trained research assistants administered the questionnaire.

In-depth Interview (IDI) was conducted using already prepared IDI guide. IDI sessions were conducted in English language only. The IDI provided detailed information on the variables that determines risks management in sports and issues not covered by the questionnaire. The interviews were recorded with digital tape recorders. In addition, non-verbal cues from the respondents were recorded through note taking. Data were collected in 2019.

\subsection{Data Analysis}

Data collected were cross-checked for completeness. Logical techniques were employed to identify errors during data cleaning. Out of the 150 copies of the questionnaire, only 138 copies did not have errors and therefore were used for data analysis. The Statistical Package for Social Sciences (SPSS) version 20.0 was employed for statistical analysis of the quantitative data. T-test statistic and Analysis of Variance (ANOVA) were used to test the null hypotheses at .05 level of significance.

Responses from the in-depth interview were not transcribed because the interviews were conducted in English Language. The NVivo 11 pro software was used to code the qualitative data and delineated according to the research objectives. Therefore, the results were presented thematically. Verbatim quotes were used to report the responses and views of the participants. Qualitative data were presented along-side the quantitative findings.

\section{Results}

\section{Hypothesis One}

There is no significant difference on risk management of sports administrators in state sports councils south-east Nigeria based on type of sport.

Table 1. T-test statistic on significant difference in the risk management of the sports administrators based on type of sports $(n=138)$

\begin{tabular}{cccccccc}
\hline $\begin{array}{c}\text { Type of } \\
\text { sports }\end{array}$ & $\mathrm{N}$ & $\bar{x}$ & $\mathrm{SD}$ & $\mathrm{df}$ & $\begin{array}{c}\mathrm{p} . \\
\text { value }\end{array}$ & $\begin{array}{c}\text { Level } \\
\text { of } \\
\text { sig. }\end{array}$ & Decision \\
\hline Team & 53 & 3.1 & 3.1 & & & & \\
\hline Individual & 85 & 3.11 & 3.09 & 136 & .423 & .05 & $\mathrm{~N} / \mathrm{R}$ \\
\hline
\end{tabular}

Key: N/R = Not rejected

Data in table 1 revealed that type of sports exerted no significant difference in risk management of the sports 
administrators. Results indicated that p-value .423 is greater than .05 , therefore, the null hypothesis of no significant difference in the risk management of the sports administrators in state sports councils south-east Nigeria based on type of sports was not rejected.

On the qualitative data, the Director of sports, Ebonyi State sports council said; 'Sports is sports, no matter the type, as long as athletes are involved, injuries must occur. Type of sports should not be used to determine risks management in sports. However, Deputy Director of sports of Anambra state sports council objected;

To me, injuries differ from sports to sports. Take for example, me that was a handball player, did I have same type of injury like scrabble or chess players? Handball is a contact game and some of the opponents I faced were very rough and you cannot compare my type of injury with my friends (athletes) that played table tennis that is not a team game.

\section{Hypothesis Two}

There is no significant difference in the risk management of the sports administrators in state sports councils south-east Nigeria according to education level.

Table 2 shows data of no significant difference in the risks management of sports administrators based on level of education. Results indicated that sig. value .45 is greater than .05 , therefore, the null hypothesis of no significant difference in the risk management of the sports administrators according to educational level was not rejected.

On this present finding from IDI, Director of sports Enugu state sports council said;

Education generally is a tool for empowerment, so when one attains a higher level of education like Master's degree and above, that person is seen as a professional in that area. In sports council, coaches that have master's degree are regarded as more professionals than those with first degree, therefore, they are expected to handle situations like risks much better. Honestly, level of education of a coach plays an important role in the management of risks in sports except if the coach in question does not want to apply the knowledge acquired to the job because of personal sentiments or reasons.

However, the Director of sports Abia state sports council said thus;

It is good that a coach attains higher level of education but it is not a factor if a coach knows how to manage risks effectively. Coaches that read texts on risks management, attend conferences and workshops very often, to me are more likely to perform or manage risks in sports better than those that go back to school to acquire more certificates. Remember, managing risks in sports is not a theory, it is practical. So paper without practical application is nothing, whether the coach is a Masters or Ph. D degree holder.

\section{Hypothesis Three}

There is no significant difference in the risk management of the sports administrators in state sports councils south-east Nigeria based on job experience.

Table 3 revealed data on the significant difference in the risks management of sports administrators based on job experience. Result indicated that sig. value .262 is greater than .05 , therefore, the null hypothesis of no significant difference in the risk management of sports administrators according to job experience was not rejected. The finding contradicts the opinion of Deputy Director of sports in Imo state sports council who said;

Experience is the best teacher in everything anyone does, even in sports, therefore, I strongly believe that any coach that has stayed more than 5years on the job should have experience on handling risks when compared to a green-horn coach. Like me, I have worked as a coach before moving to the level and position of Deputy Director of sports and because of the issues and events I have witnessed, I have a better understanding of managing risks than some of the new coaches.

Table 2. Summary of ANOVA analysis on difference in the risk management of the sports administrators based on education level ( $\mathrm{n}=138)$

\begin{tabular}{cccccccc}
\hline & Sum of square & df & $\bar{x}$ square & F & Sig.V & Level of sig. & Decision \\
\hline $\begin{array}{c}\text { Between } \\
\text { groups }\end{array}$ & 2.43 & 3 & .81 & & & & \\
\hline Within groups & 92.74 & & .69 & 1.194 & .45 & .05 & N/R \\
\hline Total & 95.17 & & & & & & \\
\hline
\end{tabular}

Table 3. Summary of ANOVA analysis on difference in the risk management of sports administrators according to job experience ( $\mathrm{n}=138$ )

\begin{tabular}{|c|c|c|c|c|c|c|c|}
\hline & Sum of square & $\mathrm{df}$ & $\bar{x}$ square & $\mathrm{F}$ & Sig.V & Level of sig. & Decision \\
\hline $\begin{array}{c}\text { Between } \\
\text { groups }\end{array}$ & 4.13 & 2 & 2.06 & & & & \\
\hline Within groups & 93.73 & & 0.74 & 2.87 & .262 & .05 & $\mathrm{~N} / \mathrm{R}$ \\
\hline Total & 97.9 & & & & & & \\
\hline
\end{tabular}




\section{Discussions}

The study was carried out to ascertain the variables of risks management among sports administrators in State sports councils, South-East, Nigeria. On type of sports, no significant difference was found among the sports administrators $(\mathrm{p}=>.05)$. This implies that risks management of sports administrators in State sports councils, South East, Nigeria do not differ based on the nature of sports they oversee. The result disagrees with (4) who compared injury incidence in youth high level athletes from various team and individual sports and found that participation in team sports entails higher injury risks, no matter the injury category. Also, records show that the highest rate of injuries was consistent with team sports $(5,6)$. However, from the interview conducted, the sports administrators differ in their views on the type of sports that predisposes athletes more to injuries. This apparently shows that risks management should differ based on type of sports a coach oversees. This is because as sports differ in nature, so would risks inherent differ, as such different approaches or strategies are required to efficiently handle the risks.

Education level did not exert significant difference in risks management of sports administrators in State sports councils, South East $(p=>.05)$. The finding implies that no matter the education attainment of sports administrators, no significant impact is made in managing risks in sports. The result stemming from the quantitative data does not support (14) who found demographic variable such as academic education to effect level of risk tolerance, of which professional values are embraced as fundamental with higher education (21), and such values could be in the area of risks management. However, the findings are in line with the findings of (17) and (16) that coach's education and qualifications impact little or none on actual coaching practice which includes risks management. From the in-depth interview, level of education was found to be pivotal for effective management of risks in sports by sports administrators.

Job experience is another variable tested to ascertain its difference on risks management of sports administrators. From the result obtained, no significant difference was found in the risks management in sports of sports administrators in State sports councils, South East, Nigeria $(p=>.05)$. This implies that job experience of the sports administrators does not in any form impact on their risks management in sports event delivery. The result from the quantitative data does not agree with (2) who found that the primary factors that influenced Florida High School Athletic Association (FHSAA) athletic director's performance of risks management behaviours were current employment status and current coaching status, and coaches with previous coaching experience perform risks management behaviours at a higher level than those with no prior coaching experience (9). The result is also in contrast with (13) who found statistic significant relationship between the athletic directors' years of experience and adoption of risks management practices in a study of risks management plans: existence and enforcement in high school athletic department in Texas. Based on the interviews conducted, job experience makes a whole lot of difference in effective risks management in sports. Coaches that have been on the job for long must have experienced and handled different forms of risks, as such possessing more capabilities than those (coaches) new on the job.

\section{Conclusions}

In conclusion, socio-demographics of the sports administrators do not significantly impact on their management of risks in sports councils/organizations in Nigeria. These findings (type of sports: $\mathrm{p}=>.05$; education level: $p=>.05$; and job experience: $p=>.05$ ) have far reaching implications in practice with the increasing rate of litigations against sports organizations. It is obvious that sports administrators in Nigeria state sports councils do not strategically evaluate and handle risks, thus their on-the-job experiences and higher education attainment are not justifiably applied to their duties. Furthermore, the findings of no statistically significant difference (type of sports: $\mathrm{p}=>.05$; education level: $\mathrm{p}=>.05$; and job experience: $\mathrm{p}=>.05$ ) show that sports management theories such as contingency theory of Joan Woodward 1956 is not applied in the management of risks among the administrators hence variables such as job experience, type of spots and level of education are not put into consideration to determine best approaches to minimize exposure of athletes to preventable injuries and reduction of possible liabilities cases and minimizing damage to sports facilities.

\section{Recommendations}

Sports administrators should endeavour to implement and practically connect ideas and knowledge gained from higher education attainment and on-the-job experience to risks management. This will enhance the need for their continuous training, especially, in area of risks management in sports. In addition, sports governing bodies should as a matter of need, organize mandatory certificate periodic seminars and trainings for the sports administrators on risks management. This will ensure that sports administrators are held accountable/responsible in event of inappropriate handling of risks in the delivery of sports activities/events.

\section{Acknowledgements}

We wish to acknowledge all our research assistants for their cooperation and hard work. 


\section{Funding}

No form of funding was received for this study

\section{Data and Materials}

The data that support the findings of this study are from different datasets such as Google, Google Scholar and institution's Library.

\section{Author's Contributions}

LC \& ON designed the research work, BU, OA \& ON carried out the data collection. LC, ON \& OA contributed to the data analysis and drafted the manuscript. All the authors read and approved the final manuscript.

\section{Ethics Approval and Consent to Participate}

Oral consents were obtained before carrying out the study. The local institutional research ethics committee, University of Nigeria, Nsukka, approved the study procedure before the study was conducted.

\section{Disclosure Statement}

The authors declare that they have no conflicting interest.

\section{ORCID}

Linda Chukwurah

https://orcid.org/0000-0002-7794-8524 


\section{Appendix 1}

\section{Questionnaire}

September 2019

Dear Respondent

Risk Management of Sports Administrators Questionnaire (RMSADsQ)

This questionnaire is designed to elicit information on risk management of sports administrators. Please read the statements carefully and tick $(\sqrt{ })$ against the response option which agrees with you. There is no right or wrong answer and be assured that the information you supply will be confidential and will be used only for the purpose of this research. Please do not write your name or your sports council on any part of the questionnaire.

Thanks for your anticipated cooperation.

Researchers

Section A (Personal Data)

Team Manager

Physiotherapist

1. Type of sports: Team

Individual/Dual

2. Level of education: NCE or OND

HND or B.Sc/ B. Ed

Masters / Ph. D

3. Years of experience
1-5 years
6-10 years
11years and above

\section{Instruction}

For each of the statements, tick $(\sqrt{ })$ as it best suits your view as follows:

\section{Guide:}

$\begin{array}{ll}\text { Always } & \text { (A) } \\ \text { Occasionally } & \text { (OC) } \\ \text { Seldom } & \text { (S) } \\ \text { Never } & \text { (N) }\end{array}$

Note: Risk is the possibility of harm or unpleasant event occurring in sports.

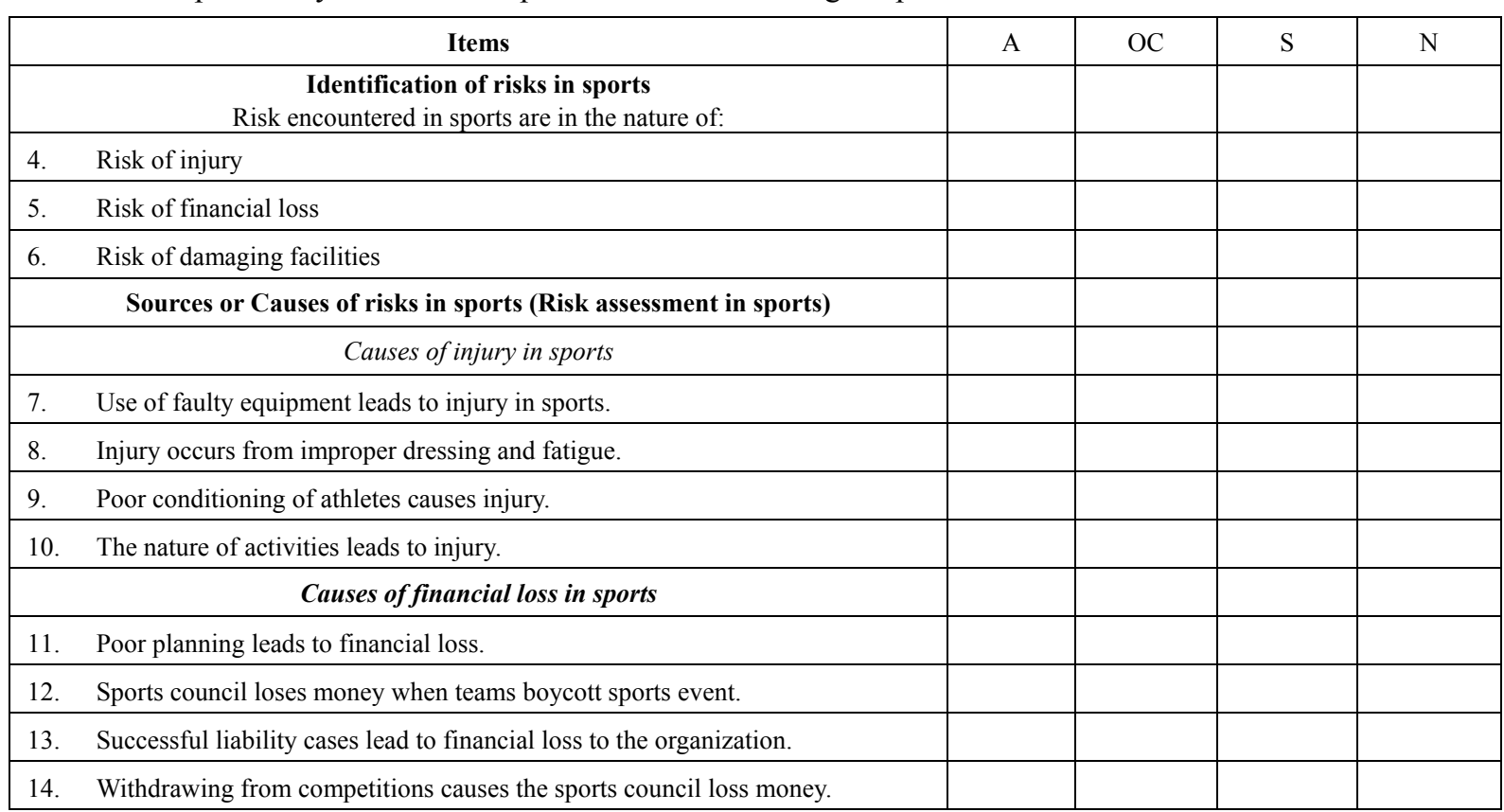


Table Continued

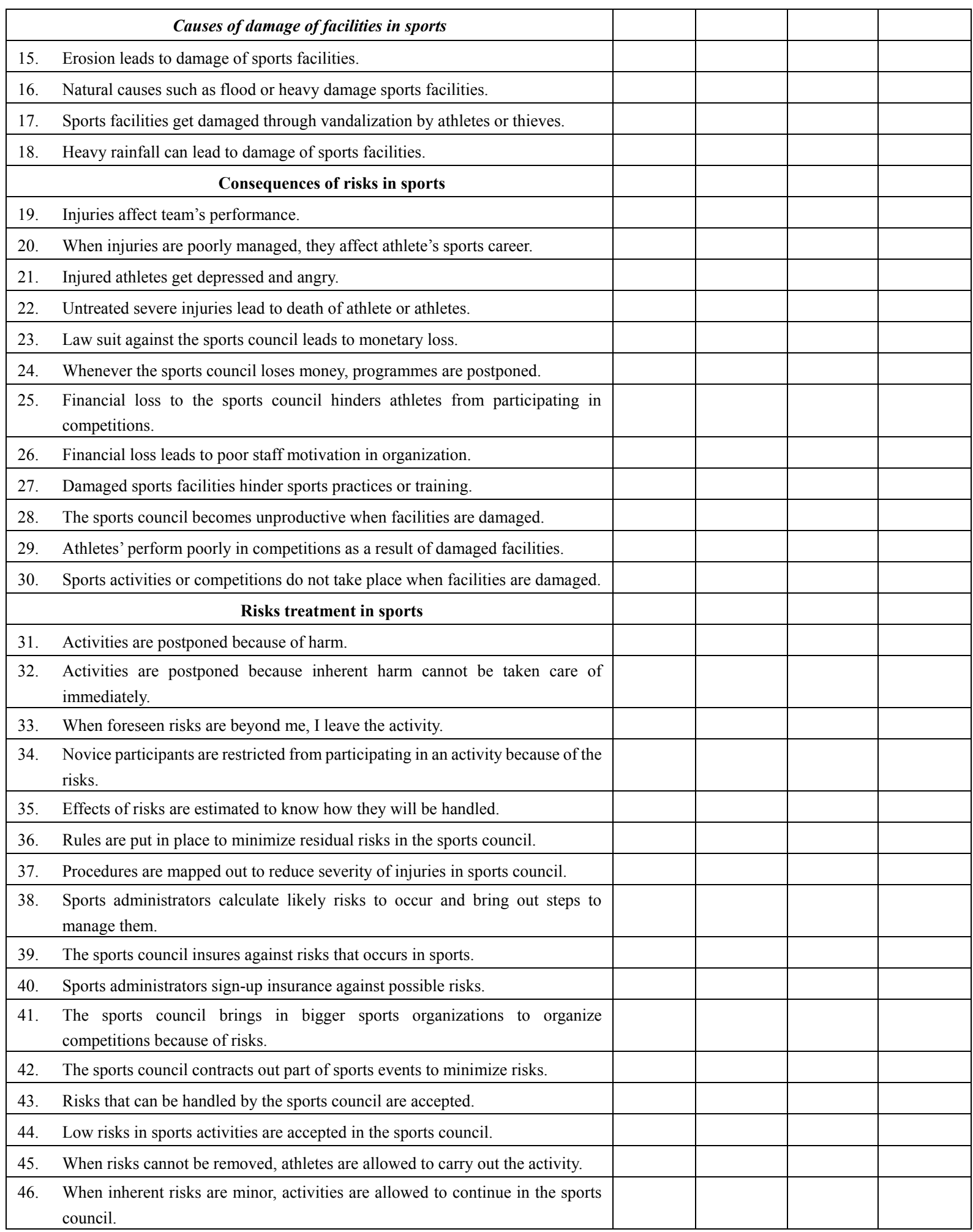


Table Continued

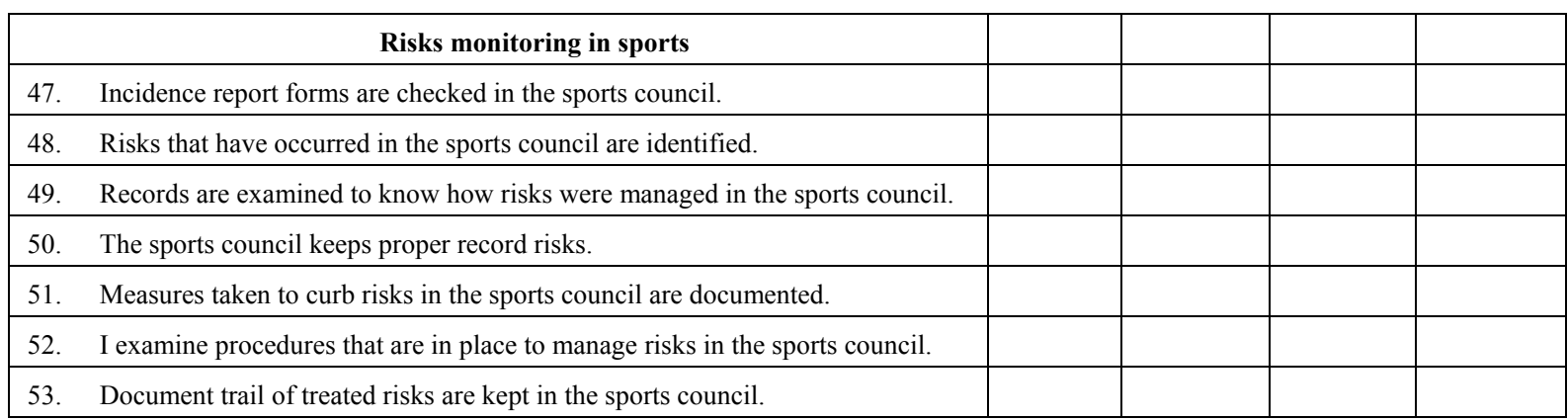

\section{Appendix II}

\section{In-depth Interview Guide for Directors and Deputy Directors of Sports}

Guide: Please respond as it best applies to you. Responses will not be used against you in any form and at any time. Therefore, verbal consent was obtained from the participants before the interview

1. Do you know the classifications/types of sports?

Probe

- State difference ways sports can be classified

2. Do you think type of sports play any role in risks management in sports among coaches?

Probe

- $\quad$ State the ways if yes

- Give reasons if no

3. What do you understand by level of education?

Probe

- $\quad$ State the different levels of education coaches can attain

- State the influence of level of education generally if any

- Explain the importance of level of education of coaches on managing risks in sports

4. Do you think a coach's job experience has any impact on risks management in sports?

Probe

- If yes, state how with reasons

- If no, state the reasons

\section{REFERENCES}

[1] M. Aghaei, M. Talebpour, A survey of risk management practices of public and private swimming pools in Khorasan Razavi, International Journal of Sport Studies, Vol. 3, No. 3, 334-338, 2013.

[2] T.C. Aaron, Factors affecting the performance levels of risk management behaviours of Florida High school athletic Directors, http://purl.flvc.org/fsu/fd/FSU migr etd-0013,
2004.

[3] T. Boyle, Health and safety: Risk management, Suffolk: IOSH Services Ltd, 2003.

[4] T. Daniel, L. Malisoux, B. Seil, Injury risk is different in team and individual youth sport, Journal of Science and Medicine in Sports, Vol. 16, No. 3, 200-204, 2013.

[5] C. Emery, Risk factors for injury in adolescent sport: A systematic review of the literature, Clinical Journal of Sport Medicine, Vol. 13, 256-268, 2003.

[6] C.A. Emery, H. Tyreman, Sports participation, sport injury, risk factors and sport safety practices in Calgary and area junior high school. Pediatrics Child Health, Vol. 14, No. 7, 439-444, 2009.

[7] I. Fullagar, Risk management for surf officials, https://lsv.com.au/wp-content/uploads/Mr-Ian-Fullagar-Ris h-Management-in-Training-and-Competition-for-Officials2011.pdf, 2008.

[8] C. Fuller, S. Drawer, The application of risk management in sport. Sports Medicine, Vol. 34, No. 6, 349-356, 2004.

[9] G.R. Gray, S.E. Crowell, Risk management behaviours in NCAA division I athletic program, Journal of Legal Aspects of Sport, Vol. 3, No. 2, 64-70, 1993.

[10] J. Hughes, A. Queenston, An introduction to sports coaching. England: Routlegde, 2007.

[11] W. James, Risk management, The University of Surrey, Guildford, Surray: GU2, 2006.

[12] P. Juan, M. Segui-Gomez, M. A. Martinez-Gonzalez, Risk of injury according to participation in specific physical activity: A 6-year following of 14, 356 participants of the Sun Cohort, International Journal of Epidemiology, Vol. 139, No. 3, 580-587, 2010.

[13] P. Mauro, A. Dotterweich, G. Lhotsky, J. Walker, Risk management practices: Existence and enforcement at NIAAA member high school athletic departments, The Sport Journal, Vol. 15, 1, 2012.

[14] N.S. Muhammad, M.I. Hafiz, The effect of demographic factors on the behaviour of investors during the choice of investment: Evidence from Twin cities of Pakistan, Global Journal of Management and Business Research: C Finance, Vol. 14, No. 3, 46-56, 2014.

[15] C.A. Miles, Legal battles in sport. Mexico: The Associate press, 2013. 
[16] S. Nash, J. Sproulc, Coaches' perception of their coach education experiences, International Journal of Sports Psychology, Vol. 43, No.1, 33-52, 2012.

[17] L.J. Nelson, C.J. Cushion, P. Potrac, Formal, non-formal and informal coach learning: A holistic conceptualization, International Journal of Sports Science and Coaching, Vol. 1, No. 3, 247-259, 2006.

[18] O.B.A. Owoeye, S.R.A. Akinbo, \& S.O. Giwa, Sports participation and injuries among undergraduate students of a Nigerian University, African Journal of Medicine and Medical Sciences, Vol. 45, No. 2, 171-178, 2016.

[19] B. Parker, New South Leaks turf fields vandalized, New York: The Washington Post, 2013.

[20] A. Schwarz, La Salle settles lawsuit with injured player for \$7.5million, NY: The New York Times, 2009.

[21] B.T. Sibandze, K.N. Scafide, Among nurses, how does education level impact professional values? A systematic review, International Nursing Review, Vol. 65, No. 1, 65-77, 2018.

[22] K. Sungon, An analysis of risk management practices and legal considerations in South Korean Sports Club, Retrieved from https://digitalrepository.unm.edu/educ_hess_etds/56?utm_s ource $=$ digitalrepository.unm.edu $\% 2$ Feduc_hess_etds $\% 2$ F5 $6 \& u t m \_$medium $=$PDF\&utm_campaign $=\mathrm{PDFCoverPages,}$ 2013.

[23] B. Van der Smissen, Legal liability and risk management of public and private entities, Cincinnati, OH: Anderson Publishing Company, 1990. 